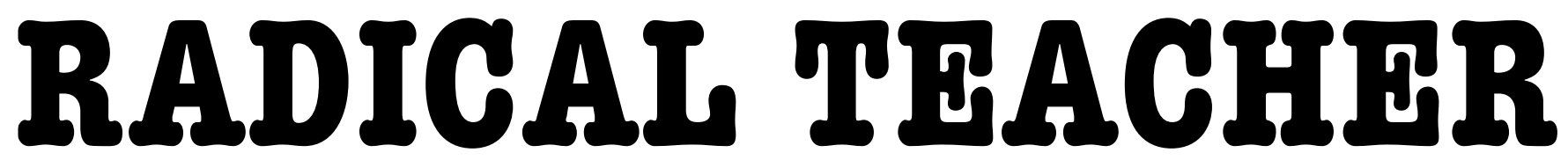

A SOCIALIST, FEMINIST, AND ANTI-RACIST JOURNAL ON THE THEORY AND PRACTICE OF TEACHING

\title{
Bread Givers
}

(RADICAL TEACHER NO.55, 1999)

by Joseph Entin

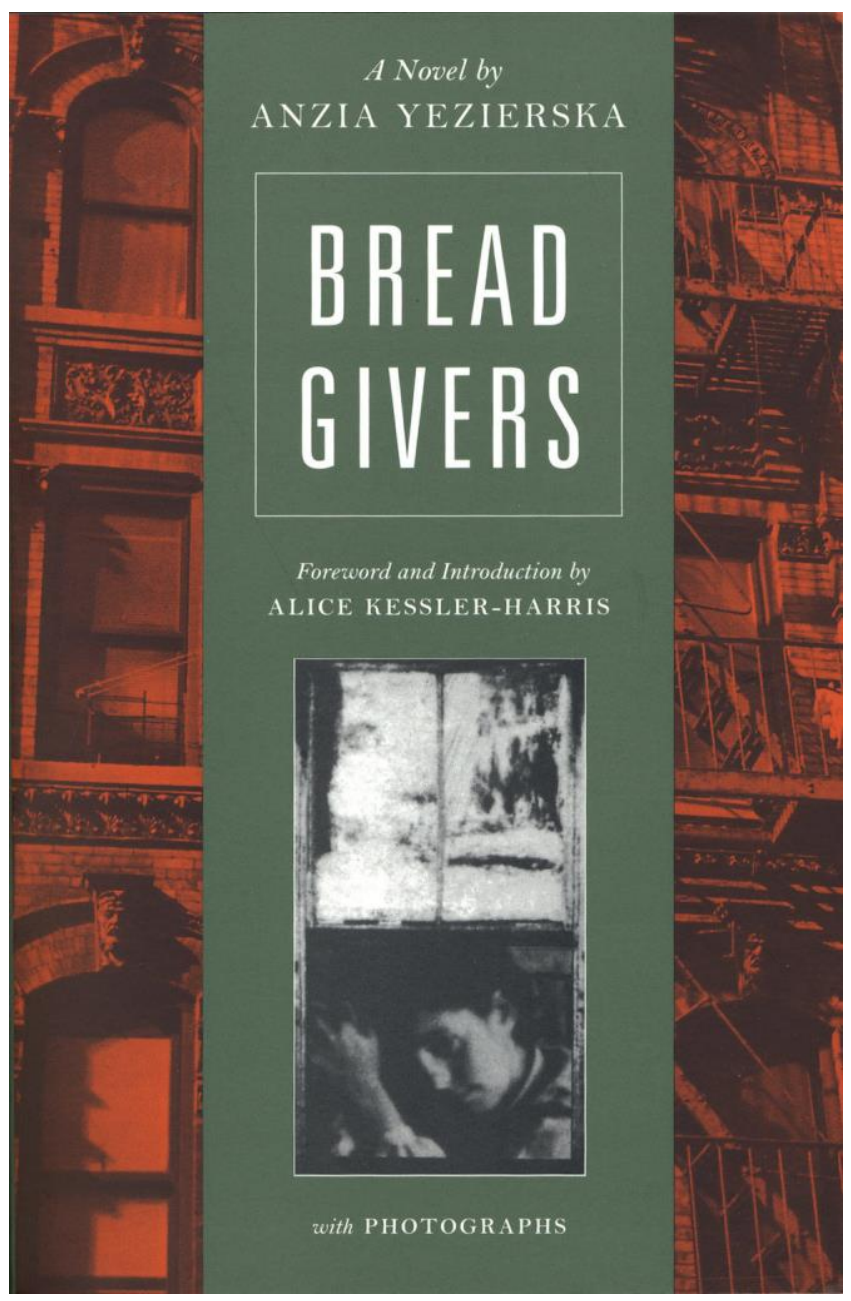

BREAD GIVERS. ANZIA YEZIERSKA. (PERSEA BOOKS, 1925) 
Bread Givers. Anzia Yezierska. Persea Books.

$\mathrm{T}$

eaching Anzia Yezierska's Bread Givers at an elite university, I've discovered that students typically find the novel very pleasurable, even reassuring. At first glance, it offers a straight-forward rendering of a familiar tale: immigrant girl "assimilates" and makes good, leaving behind oppressive Old World customs for New World independence and professionalism. In addition, the novel seems to offer direct access to the immigrant experience, a genuine slice of Jewish-American experience, a look at "the way it really was." This notion is reinforced by the novel's introduction, written by social historian Alice Kessler-Harris. Kessler-Harris contends that in the novel Yezierska "opens the door wide and leads us" into ghetto life, "plunging us directly into the woman's experience of immigration." In addition, she states that "Anzia Yezierska and Sara Smolinsky, the novel's narrator, are emotionally interchangeable."

To understand the novel as a "direct" transcription, rather than an imaginative translation, of "authentic" experience is to cast Yezierska as a mere scribe, rather than a cultural agent, and to imply that literature represents unmitigated access to "truth" rather than a highly-mediated ideological act. And to believe this is to place ourselves as readers in positions of power over the figures and culture we are reading about -- we understand them, we tell ourselves, we know the "truth" about their experience. When teaching Bread Givers, I aim to move students away from this seductively safe and reassuring way of reading towards an understanding of the ways in which literary narratives, no matter how seemingly "simple," are always already complex acts of rhetorical and cultural power. As Fredric Jameson argues in The Political Unconscious, narratives of socially marginalized groups must be placed within a crowded field of ideological contestation: "[T]he affirmation of . . . nonhegemonic voices remains ineffective if it is limited to the merely 'sociological' perspective of the pluralistic rediscovery of other isolated groups: only an ultimate rewriting of these utterances in terms of their essentially polemic and subversive strategies restores them to their proper place in the dialogical system of the social classes."

Rather than as social history, then, Bread Givers can more productively be read as what Kenneth Burke, in The Philosophy of Literary Form, calls "equipment for living": "strategies for selecting enemies and allies, for socializing losses, for warding off evil eye, for purification, propitiation, and desanctification, consolation and vengeance."

To give students a sense of the ways in which Bread Givers functions as "equipment for living," I often begin by introducing one of the "allies" whom the novel won for its author -- William Lyon Phelps, renowned Yale University Shakespeare scholar who gave Yezierska's novels high praise when they were published during the 1920s. Phelps, a high-culture gate-keeper, lauded Yezierska's writing on much the same terms as Kessler-Harris does: "Her stories, both of the poor and their dreams, are authentic," he wrote. "There was so much style in some of the books by Meredith and Henry James that it got between the reader and the object . . . but in Yezierska's tales there is nothing. One does not seem to read; one is too completely inside."

Support from figures like Phelps helped Yezierska to succeed in the commercial culture of American letters -success that entailed life choices quite different from Sara Smolinsky's. While Bread Givers ends with Sara's marriage to a fellow Jew and reconciliation with her father, Yezierska herself abandoned her husband and daughter to pursue a professional writing career. Phelps's praise of Yezierksa's fiction and the significant differences between author and protagonist raise several provocative questions for discussion. Why did Phelps find Bread Givers so appealing, so reassuring? How do we account for the contrasting personal and professional lives of Yezierska and Sara -- why doesn't Yezierska have Sara leave teaching and her husband to pursue a writing career? If the novel confirms Phelps's way of seeing on several levels, does it also smuggle in certain challenges to the worldview of readers like Phelps? Does the novel lack literary "style," as Phelps suggests -- or is the very appearance of simplicity actually a form of "style" that Yezierska, an accomplished professional writer, created? Such questions lead back to the text itself, but with a new agenda for reading that focuses on the novel as an artifact that performs cultural work, that is engaged in -and continues to be an object of -- ideological struggle. (c)) EY-NO-ND

ULLS D-Sorle
This work is licensed under a Creative Commons Attribution-Noncommercial-No Derivative Works 3.0 United States License.

This journal is published by the University Library System of the University of Pittsburgh as part of its D-Scribe Digital Publishing Program, and is cosponsored by the University of Pittsburgh Press.
RADICAL TEACHER
No. 113 (Winter 2019) 